Tersedia online di: http://ejournal-balitbang.kkp.go.id/index.php/jkpt

\title{
INDIKATOR KELIMPAHAN SUMBERDAYA IKAN SIRO (Amblygaster sirm) DI LAUT JAWA
}

\section{STOCK INDICATOR OF SPOTTED SARDINELLA (Amblygaster sirm) IN THE JAVA SEA}

\author{
Rudy Masuswo Purwoko\#, Andhika Prima Prasetyo dan Nurulludin \\ Pusat Riset Perikanan \\ Jl. Pasir Putih II, Ancol Timur, Jakarta Utara !4430 \\ E-mail: rudylhia@gmail.com
}

(Diterima: 15 Agustus 2019; Diterima setelah perbaikan: 1 September 2019; Disetujui: 1 September 2019)

\begin{abstract}
ABSTRAK
Pemanfaatan ikan siro (Amblygaster sirm) di Laut Jawa menunjukkan gejala overfishing. Beberapa aksi pengelolaan telah dilakukan untuk mengatasinya dan efektifitasnya dipertanyakan. Penelitian ini bertujuan untuk memperbaharui status populasi ikan siro di Laut Jawa dengan menggunakan beberapa indikator, yakni kelimpahan dan biologi. Pengumpulan data dilakukan di Pelabuhan Perikanan Nusantara (PPN) Pekalongan selama 6 bulan (Oktober 2013 - Maret 2014). TropFishR package digunakan untuk menganalisis beberapa parameter pada 830 individu. Hasil penelitian menunjukkan ukuran panjang berkisar antara 14,1-24.5 cmFL. Parameter pertumbuhan ikan siro (Linf, $\mathrm{K}$ dan $\mathrm{t}_{0}$ ) masing-masing sebesar $21.9 \mathrm{cmFL}, 1,7 /$ tahun dan 0,45. Perbandingan antara jumlah kelamin jantan dan betina dalam kondisi seimbang. Pola pertumbuhan ikan siro bersifat alometrik negatif $(2,259)$, dimana pertumbuhan panjang lebih cepat dari pertumbuhan beratnya. Ukuran panjang pertama kali matang gonad (Lm) dan ukuran panjang pertama kali tertangkap (Lc) masing-masing sebesar 16,8 cmFL dan 15,4 cmFL. Indikator kelimpahan menunjukkan kecenderungan penurunan. Selain itu, Lc lebih kecil dari Lm yang mengindikasikan terjadinya growth overfishing.
\end{abstract}

\section{KATA KUNCI: Indikator stok; ikan siro; Laut Jawa}

\begin{abstract}
The exploitation of spotted sardinella (Amblygaster sirm) in the Java Sea indicates overfishing phenomenon. Several management measures implemented to address that issue but the effectiveness is questionable. This research aims to update the population status of spotted sardinella in Java Sea using several indicators i.e. abundance and biological indicators. Data collection conducted in Archipelago Fishing Port (AFP) Pekalongan within 6 months (October 2013 - March 2014). TropFishR package used to analyzed several paramters for 830 individual. The result showed the length was 14,1-24.5 cmFL. Growth parameters (Linf, $K$ and $t_{0}$ ) of spotted sardinella was $21.9 \mathrm{cmFL}, 1.7 /$ year and 0.45 . The sex ratio was equal, while the growth pattern was negative allometric $(2,259)$ that length growth was faster than weight. The length at first mature $(\mathrm{Lm})$ and the length at first capture $(\mathrm{Lc})$ were $16,8 \mathrm{cmFL}$ and $15,4 \mathrm{cmFL}$ respectively. The abundance indicated an decresed biomass. Moreover, Lc was lower than Lm indicates growth overfishing occurred.
\end{abstract}

KEYWORDS: Stock indicator; spotted sardinela; Java Sea

\# Korespondensi: Pusat Riset Perikanan

E-mail: rudylhia@gmail.com 


\section{PENDAHULUAN}

Pemanfaatan ikan siro (Amblygaster sirm) telah dilakukan sejak lama di Laut Jawa khususnya dengan menggunakan pukat cincin mini. Beberapa kajian menunjukkan bahwa populasi ikan siro di Laut Jawa mengalami biological overfishing (Atmaja \& Nugroho, 1995; Atmaja, 2006; Atmaja \& Nugroho, 2004; Wijopriono \& Genisa, 2003). Beberapa peraturan diterbitkan untuk mengatasi hal tersebut, seperti Peraturan Menteri Kelautan dan Perikanan Nomor 3 tahun 2014 tentang rencana strategis kementerian kelautan dan perikanan tahun 2010 - 2014 menyatakan bahwa produksi perikanan tangkap nasional adalah sebesar 5,44 juta ton di mana kenaikkannya kurang dari $8 \%$ dari tahun sebelumnya. Nilai produksi nasional yang demikian perlu di perhatikan dan dikaitkan dengan overfishing komoditas jenis ikan tertentu demi keberlanjutan kegiatan perikanan laut. Aturan untuk mengatasi overfishing ditinjau dari aspek alat tangkap adalah dari besaran ukuran mata jaring yang digunakan, Peraturan Menteri Kelautan dan Perikanan Nomor 18 tahun 2013 tentang Perubahan Ketiga Atas Peraturan Menteri Kelautan dan Perikanan Nomor 02 tahun 2011 mengatur tentang jalur penangkapan ikan dan penempatan alat penangkapan ikan dan alat bantu penangkapan ikan di wilayah pengelolaan perikanan negara republik Indonesia.

Pelabuhan Perikanan Nusantara (PPN) Pekalongan merupakan salah satu lokasi pendaratan ikan utama di Laut Jawa. Kelimpahan ikan siro pernah dibuktikan dengan mendominasi hasil tangkapan ikan pelagis yang didaratkan di PPN Pekalongan sebesar 47\% (Kasim et al., 2014) dan produksinya pada tahun 2015 sebesar 2.720 ton, dibandingkan produksi tahun 2014 yang mencapai 3.747 ton kondisi ini menunjukkan penurunan. Ikan siro di PPN Pekalongan menjadi komoditas ikan ekonomis penting di Provinsi Jawa Tengah karena harganya yang relatif terjangkau oleh masyarakat kecil terutama pengolah ikan yang membutuhkan bahan baku yang lebih murah.

Sejak tahun 2009 kelangkaan bahan baku lemuru (Sardinella lemuru) yang terjadi di Selat Bali yang diduga disebabkan oleh variabilitas iklim yang menyebabkan lemuru terdistribusi di perarian lebih dalam dan tidak terjangkau oleh alat tangkap (Prasetyo \& Natsir, 2010). Siro merupakan bahan baku substitusi bagi industri tepung dan pengalengan ikan sardine di Jawa Timur. Berdasarkan data produksi perikanan tangkap Dinas Kelautan dan Perikanan Jawa Tengah tahun 2009, Ikan siro biasa diolah menjadi produk ikan asin terutama oleh pengolah kecil dan menengah. Olahan ikan asin tidak hanya di konsumsi oleh masyarakat di sekitar Pekalongan saja, namun dipasarkan juga di beberapa wilayah Jawa Tengah, Jawa Barat, Jawa Timur, Jakarta dan Lampung.

Beberapa indikator digunakan untuk menilai kesehatan stok suatu perikanan, diantaranya indikator kelimpahan dan biologi reproduksi. Indikator kelimpahan umumnya merujuk pada hasil tangkapan per satuan upaya (catch per unit effort) sebagai indek relative dari kelimpahan sumberdaya. Selain itu indikator biologi sering kali digunakan untuk mengkaji status stok, seperti perbandingan antara ukuran pertama kali matang gonad $(\mathrm{Lm})$ dan ukuran rata-rata tertangkap (Lc). Beberapa studi biologi reproduksi terdahulu menunjukkan bahwa pemijahan ikan siro dipengaruhi oleh musim barat dan musim timur (Jayasuriya, 1989). Pada bulan Oktober - Nopember ikan berukuran sedang dan bulan Desember - Februari ikan berukuran besar (Atmaja, 2006). Ikan siro di Laut Jawa siap memijah pada bulan Februari - Juni dan belum siap memijah pada bulan Agustus - Januari (Atmaja \& Nugroho, 1997).

Permintaan ikan siro untuk dikonsumsi masyarakat dan oleh pengolah sebagai bahan baku pembuatan ikan asin secara tidak langsung menuntut nelayan pukat cincin mini untuk terus melakukan operasi penangkapan. Seiring waktu berjalan, dengan semakin bertambahnya armada pukat cincin mini dan lokasi penangkapannya yang semakin jauh dari perairan pantai serta diduga tertangkapnya ikan siro muda yang belum sempat memijah telah menunjukkan besarnya kegiatan eksploitasi terhadap sumberdaya ikan ini. Beberapa perangkat pengelolaan telah diterbitkan untuk mengatasi ovefishing pada perikanan ini, namun efektifitasnya terhadap perbaikan stok ikan siro dipertanyakan. Penelitian ini bertujuan untuk memperbaharui status populasi ikan siro dengan menggunakan beberapa indikator, yakni indikator kelimpahan dan biologi reproduksi. Harapannya hasil penelitian dapat digunakan untuk masukan bagi pengelolaan dan dasar bagi penelitian selanjutnya.

\section{BAHAN DAN METODE}

Penelitian dilakukan dari bulan September 2013 sampai dengan bulan Maret 2014. Ikan contoh diperoleh dari hasil tangkapan pukat cincin mini yang didaratkan di Pelabuhan Perikanan Nusantara Pekalongan. Ikan diukur panjang cagaknya (FL) dalam centimeter dan ditimbang berat tubuhnya dalam gram.

Indeks kelimpahan / catch per unit of effort hasil tangkapan mini purse seine (MPS) dan hasil tangkapan jenis ikan siro dikelompokkan setiap tahun (20112015) sehingga didapatkan total hasil tangkapan dan jumlah hari operasi yang kemudian akan menghasilkan indeks kelimpahan total, dihitung menggunakan 
rumus:

$$
\mathrm{CPUE}=\mathrm{C} / \mathrm{O}
$$

CPUE $=$ indeks kelimpahan setiap tahun (2011-2015)

$\mathrm{C} \quad=$ hasil tangkapan MPS / jenis ikan siro tiap tahun

$\mathrm{O}=$ jumlah hari dilaut atau lama operasi (tiap tahun)

Untuk mengetahui pola pertumbuhan ikan siro digunakan rumus hubungan panjang dan berat ikan sebagai berikut (Effendie, 2002):

$$
\mathrm{W}=\mathrm{aL}^{\mathrm{b}}
$$

Dimana :

$\mathrm{W}=$ berat ikan (gram)

$\mathrm{L}=$ panjang ikan $(\mathrm{cm})$

a dan b konstanta

Analisis parameter pertumbuhan (Linf, $\mathrm{K}$ and $\mathrm{t}_{0}$ ) diduga dengan menggunakan paket TropFishR
(Mildenberger, Taylor, \& Wolff, 2017). ELEFAN II with genetic algoritm used to allow optimasion of VBGF (Taylor \& Mildenberger, 2017).

$\mathrm{Lt}=\mathrm{L}_{\infty}(1-\exp (-(\mathrm{K}(\mathrm{t}-\mathrm{t} 0))$

dimana Lt adalah panjang pendugaan, Linf adalah panjang teoritis, $\mathrm{K}$ koefisien pertumbuhan $\mathrm{t}$

Dimana :

Lt : panjang ikan pada umur $\mathrm{t}$ satuan waktu

Linf : panjang maksimum atau panjang asimtotik

$\mathrm{K}$ : koefisien pertumbuhan

t0 : umur ikan pada saat panjang sama dengan nol

Penentuan tingkat kematangan gonad dilakukan secara visual dengan mengacu 5 tingkat kematangan gonad berdasarkan perbedaan tekstur warna dan besarnya gonad (Effendie, 2002).

Tabel 1. Penentuan tingkat kematangan gonad

\begin{tabular}{|c|c|c|}
\hline T K G & Jantan & Betina \\
\hline I & $\begin{array}{l}\text { Gonad sangat kecil seperti benang } \\
\text { dan transparan. Lebih pendek dari } \\
\text { gonad ikan betina. Penampang } \\
\text { gonad pipih dengan warnakelabu. }\end{array}$ & $\begin{array}{l}\text { Bentuk gonad kecil dan transparan, } \\
\text { Penampang gonad ikan betina } \\
\text { tampak bulat dengan warnakemerah- } \\
\text { merahan }\end{array}$ \\
\hline II & $\begin{array}{l}\text { Permulaan masak. Gonad mengisi } \\
\text { seperempat rongga tubuh. Warna } \\
\text { gonad pada ikan jantan kelabu atau } \\
\text { putih. }\end{array}$ & $\begin{array}{l}\text { Awal masak, gonad mulai membesar, } \\
\text { kira-kira setengah rongga tubuh. } \\
\text { Telurtidaktampak. }\end{array}$ \\
\hline III & $\begin{array}{l}\text { Hampir masak. Gonad mengisi } \\
\text { setengah ronggatubuh. Gonad pada } \\
\text { ikan jantan berwarna putih keruh } \\
\text { (tidak tembus cahaya) }\end{array}$ & $\begin{array}{l}\text { Hampir masak, gonad pada ikan } \\
\text { betina berwarna kuning kemerah- } \\
\text { merahan. Bentuk telur tampak } \\
\text { melaluidinding ovari. }\end{array}$ \\
\hline IV & $\begin{array}{l}\text { Masak. Gonad mengisi } \quad \text { tiga } \\
\text { perempat rongga tubuh. Gonad } \\
\text { jantan berwarna putih berisi cairan } \\
\text { berwarna putih keruh/coklat muda. }\end{array}$ & $\begin{array}{l}\text { Masak. Gonad betina berwarna merah } \\
\text { muda, Telur mulai terlihat. Kadang- } \\
\text { kadang dengan tekanan halus pada } \\
\text { perutnya maka akan ada yang } \\
\text { menonjol pada lubang pelepasannya. }\end{array}$ \\
\hline V & $\begin{array}{l}\text { Salin. Ukuran hampir sama dengan } \\
\text { tahap kedua dan sukar dibedakan. } \\
\text { Gonad jantan berwarna putih, } \\
\text { kadang-kadang } \text { dengan bintik } \\
\text { cokelat. }\end{array}$ & $\begin{array}{l}\text { Salin. Hampir sama dengan tahap } \\
\text { kedua dan sukar dibedakan. Gonad } \\
\text { betina berwarna merah, lembek dan } \\
\text { b. }\end{array}$ \\
\hline
\end{tabular}

Table 1. Determination of gonad maturity level

Sumber: (Effendie, 2002) 
Nilai ukuran rata-rata tertangkap $\left(\mathrm{L}_{50 \%}\right.$ ikan siro didapatkan dengan menghitung frekuensi kumulatif panjang cagak ikan, sehingga terbentuk titik potong antara kurva logistik baku dengan persentase frekuensi kumulatif panjang cagak 50\% yang akan dinyatakan sebagai rata-rata panjang ikan siro yang tertangkap (Wujdi et al, 2013). Formulasi perhitungan dengan excel menggunakan persamaan (Hoydal, Rorvik, \& Sparre, 1982), yaitu :

$$
\mathrm{SL}_{50 \%}=\frac{\mathrm{S} 1}{\mathrm{~S} 2}
$$

Dimana:

$\mathrm{SL}=$ kurva logistik

$\mathrm{a}=$ koefisien intersep; $\mathrm{b}=$ slope; $\mathrm{e}=$ eksponensial (nilainya $=2.71828)$; dan $\mathrm{S} 1=\mathrm{a}$

$\mathrm{S} 2=\mathrm{b}$

$$
\mathrm{S}_{\text {Lestimasi }}=\frac{1}{1+\exp (\mathrm{S} 1-\mathrm{S} 2 * \mathrm{~L})}
$$

Dimana :

$\mathrm{S}_{\text {Lestimasi }}=$ Straight line kurva maksimum

$\mathrm{S}_{\text {Lobservasi }}=$ Straight line $\mathrm{x}, \mathrm{y}$

S1 $=$ intercept

$$
\begin{array}{ll}
\mathrm{S} 2 & =\text { slope } \\
\mathrm{L} & =\mathrm{L} 50 \% \text { (ukuran rata-rata ikan tertangkap) }
\end{array}
$$

\section{HASIL DAN PEMBAHASAN}

\section{Hasil}

\section{Parameter Pertumbuhan}

Pengambilan ikan contoh dilakukan sebanyak 6 kali dimulai pada bulan Oktober 2013 sampai bulan Maret 2014 dilakukan secara acak pada kapal mini purse seine untuk mendapatkan data frekuensi panjang (Gambar. 1). Hasil penelitian yang pernah dilakukan menunjukkan bahwa frekuensi panjang ikan siro bervariasi mulai dari bulan Oktober - Februari (Atmaja, 2006).

Hasil analysis parameter pertumbuhan dengan menggabungkan keseluruhan data (jantan dan betina) diperoleh Linf, $\mathrm{K}$ dan $\mathrm{t}_{0}$ masing-masing sebesar 21.9 cmFL, 1,7/tahun dan 0,45 (Gambar 1). Nilai K lebih besar dari 1 menujukkan bahwa ikan siro termasuk jenis ikan yang memiliki pertumbuhan yang cepat. Sebaran ukuran panjang berdasarkan sampel ikan siro dengan jumlah total 830 ekor adalah 14,1-24,5 cmFL yang dengan dominan ukuran panjang sebesar 14,8 cmFL (Gambar. 2)

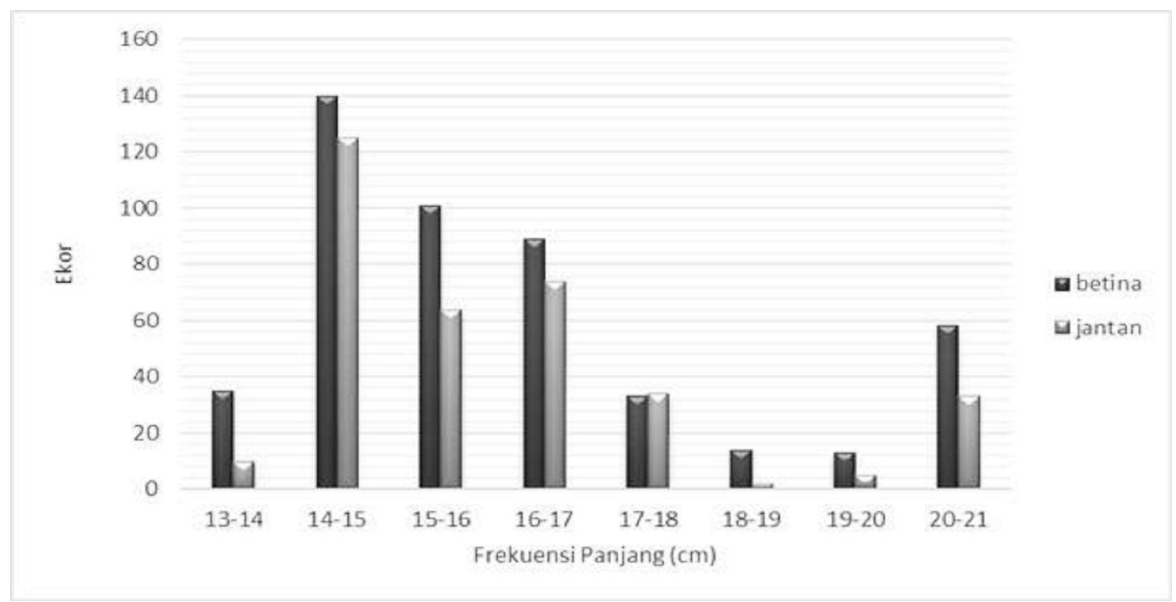

Gambar 1. Frekuensi panjang ikan siro.

Figure 1. Length frequency of spotted sardinella.

\section{Indikator Biologi}

Berdasarkan analisis hubungan panjang-berat diperoleh nilai $b=2,2598$, yang menunjukkan bahwa sifat pertumbuhan ikan siro adalah alometrik negatif (Gambar 3).

\section{Panjang Tertangkap (Lc)}

Indikator biologi dalam kontek penilaian kondisi kelimpahan sumberdaya ikan dilihat berdasarkan perbandingan antara ukuran panjang pertama kali ikan tertangkap (length at first capture/Lc) dan panjang ikan pertama kali matang gonad (length at first maturity/ $\mathrm{Lm})$. Ditemukan rata - rata ikan siro yang tertangkap oleh pukat cincin mini pada umumnya belum matang gonad, sementara itu dalam analisis frekuensi panjang ikan siro hasil tangkapan pukat cincin mini selama periode penelitian diperoleh ukuran panjang pertama kalitertangkap (Lc) ikan siro sebesar 15,4 cm (Gambar 4). 


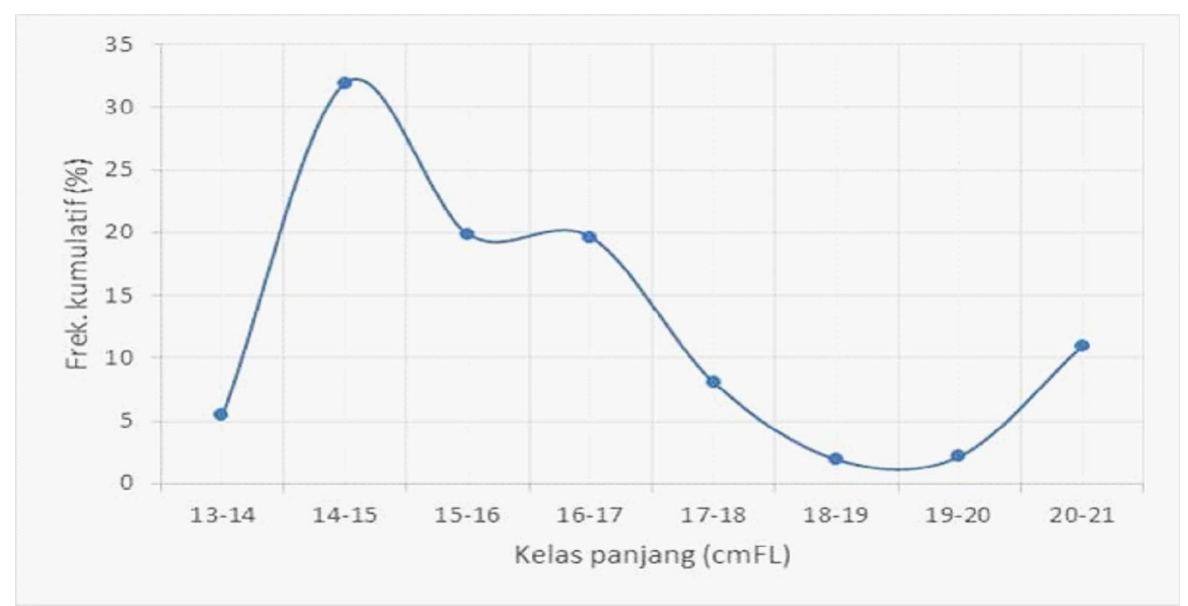

Gambar 2. Sebaran frekuensi panjang ikan siro.

Figure 2. Length-frequency data of spotted sardinella.

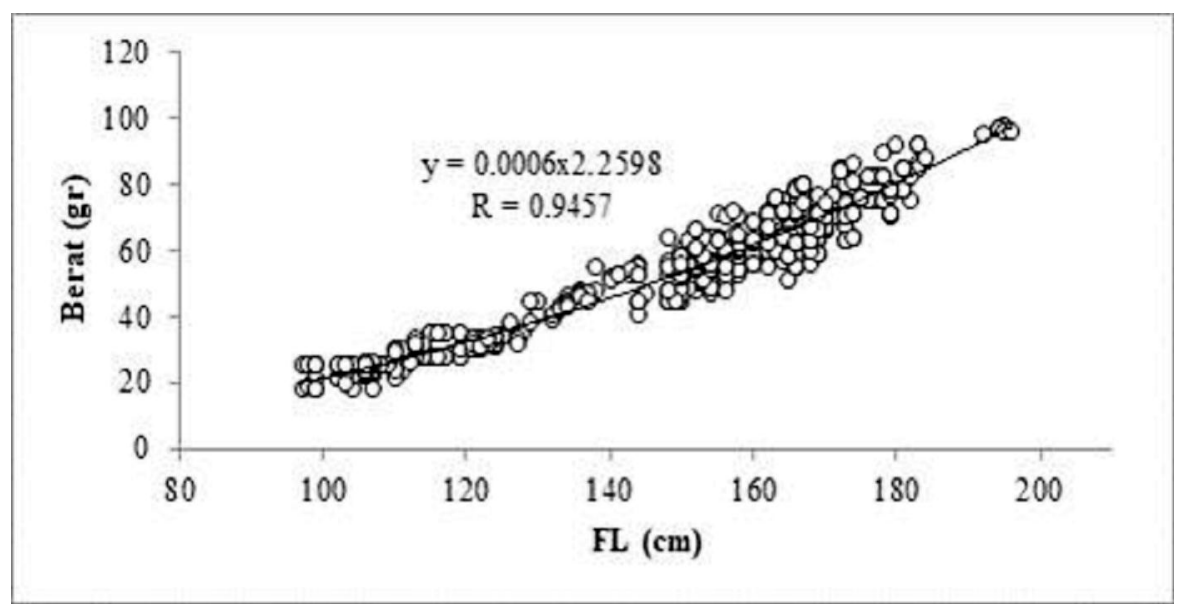

Gambar 3. Hubungan panjang berat ikan siro.

Figure 3. Length-weight realationship of siro.

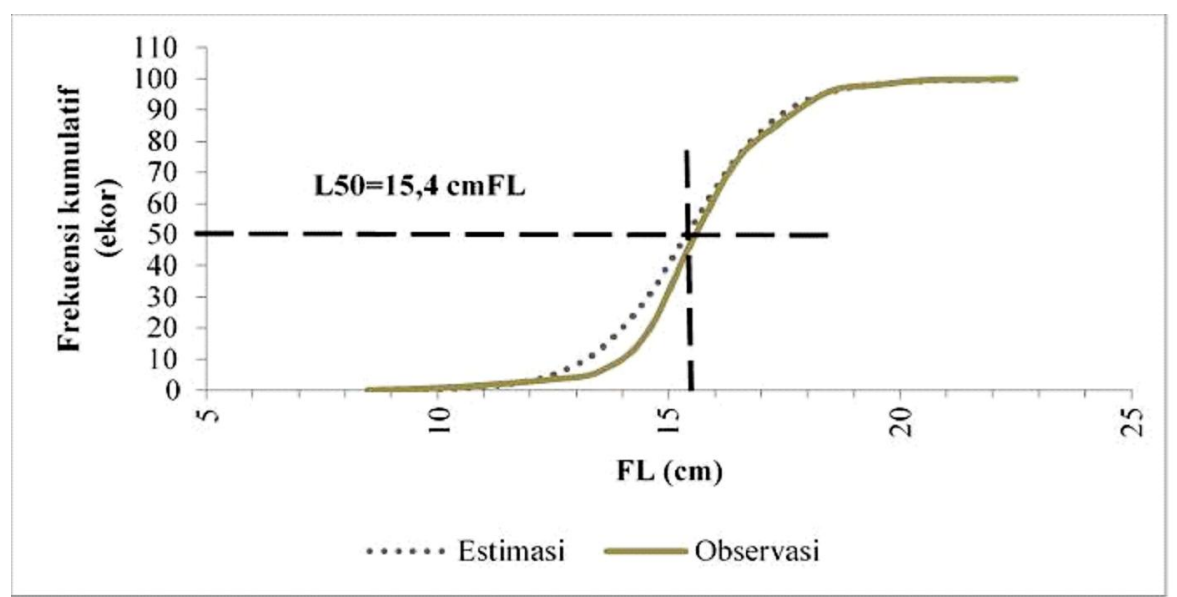

Gambar 4. Pendugaan panjang pertama kali tertangkap.

Figure 4. The estimation of length at first capture.

Hasil pengamatan terhadap jenis kelamin sampel 449 ekor siro betina dan 381 ekor siro jantan menunjukkan bahwa nisbah kelamin (sex ratio) dari stok ikan siro jantan dan betina dalam kondisi seimbang (Gambar 5). 
Ikan siro pada tingkat kematangan gonad (TKG) III dianggap sebagai ikan siro yang pertama kali matang gonad secara visual (Lm). TKG I baik dari ikan siro jantan dan betina lebih banyak tertangkap bila dibandingkan dengan TKG II dan III. Jumlah sampel ikan siro berdasarkan TKG dan jenis kelamin ditampilkan pada Gambar 6.

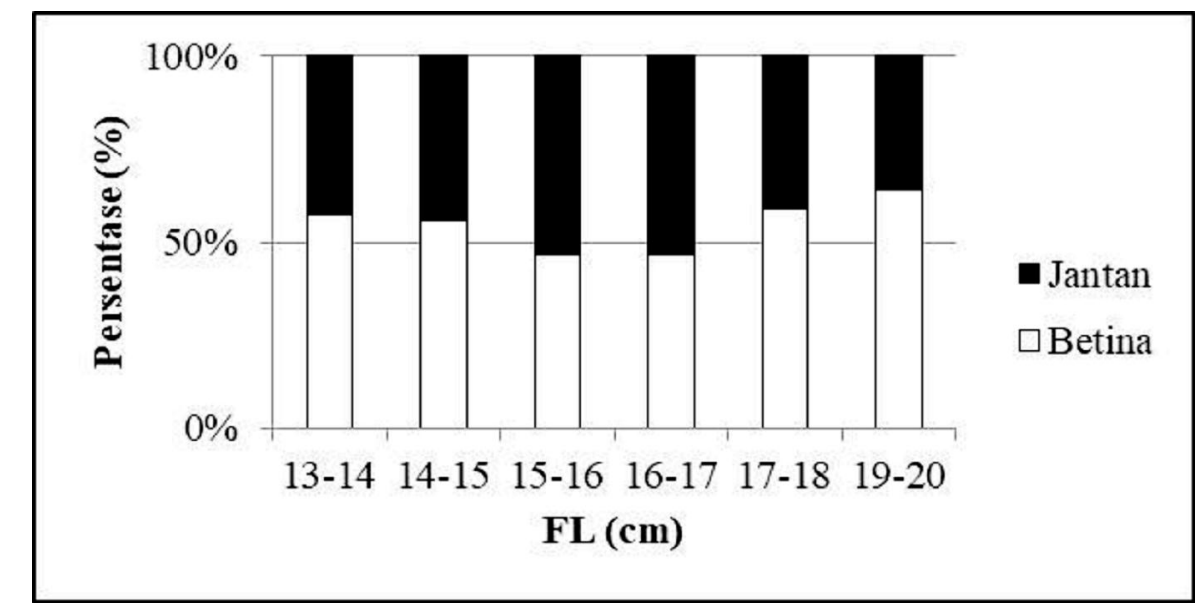

Gambar 5. Nisbah kelamin ikan siro.

Figure 5. Sex ratio of siro.

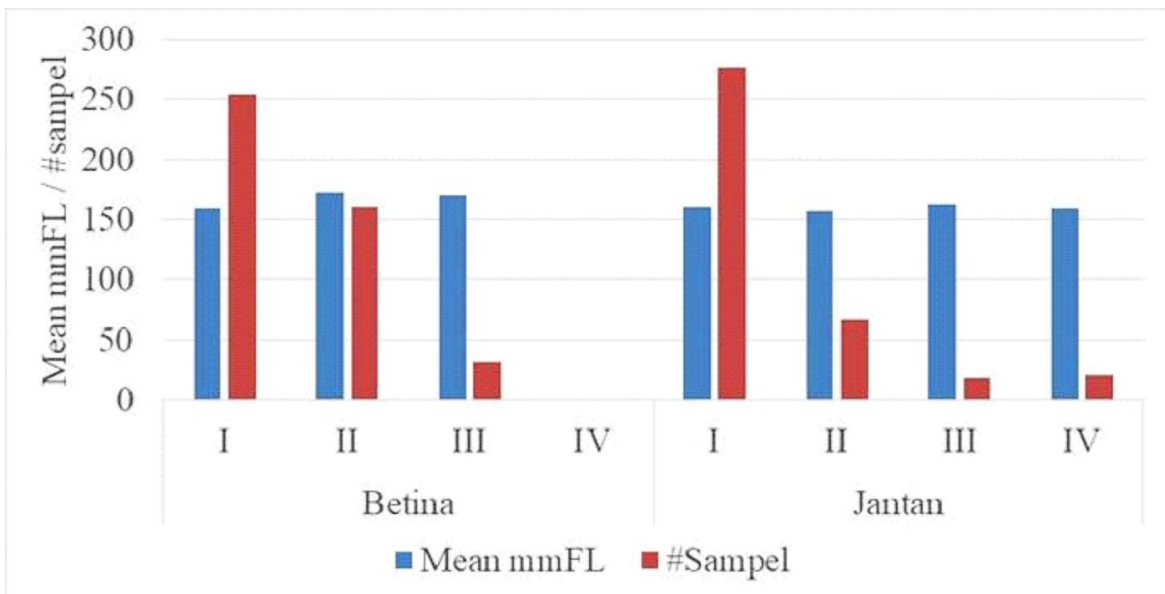

Gambar 6. Perbandingan rata - rata ukuran dan jumlah individu berdasarkan TKG dan Jenis Kelamin.

Figure 6. Comparison average of mmFL and Number of Individu across GSI and Sex.

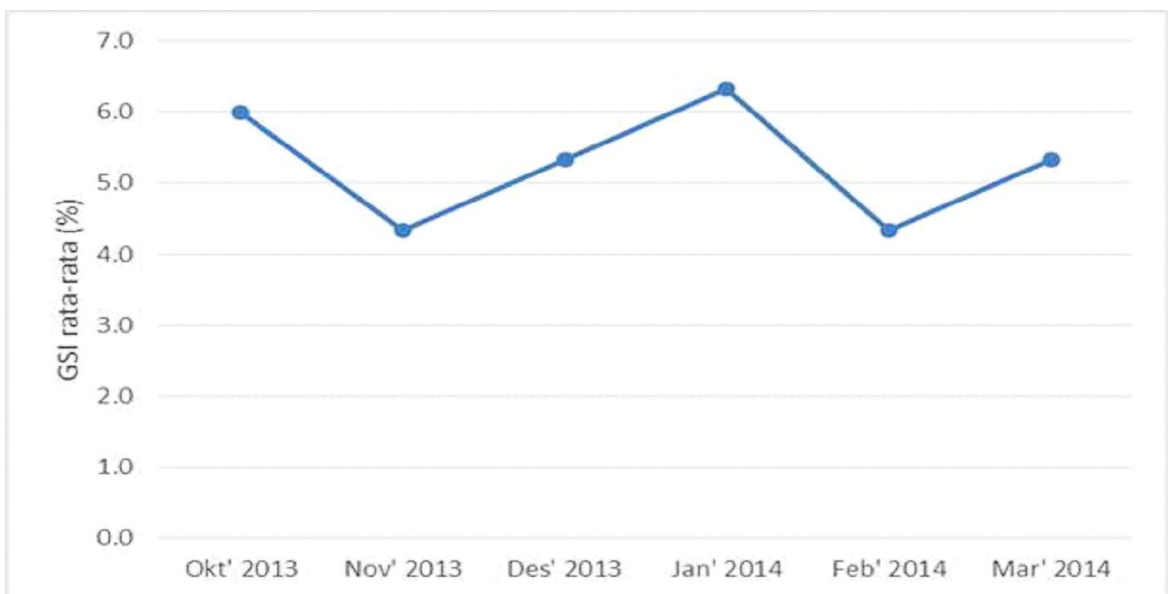

Gambar 7. Rata-rata nilai indeks kematangan gonad siro.

Figure 7. Average gonado somatic index of siro. 
Pada umumnya perkembangan kematangan gonad dilihat dari nilai indeks kematangan gonad yang ditunjukkan melalui fluktuasi nilai setiap bulannya. Pengamatan terhadap sampel ikan siro jantan dan betina menunjukkan bahwa nilai indeks kematangan gonad pada saat puncaknya $(6,1 \%-6,3 \%)$ terjadi pada bulan Oktober dan Januari dan turun pada bulan November dan Februari $(4,2 \%$ - 4,3\%) (Gambar. 7).

\section{Indikator Kelimpahan}

Biomassa ikan siro (A. sirm) berdasarkan data pendaratan menunjukkan kecenderungan yang terus menurun (Gambar 8). Pada kurun waktu 2002-2015, kelimpahan biomassa ikan siro menurun hampir $74 \%$, dari 31.135 ton pada tahun 2002 menjadi 8.120 ton pada tahun 2015.

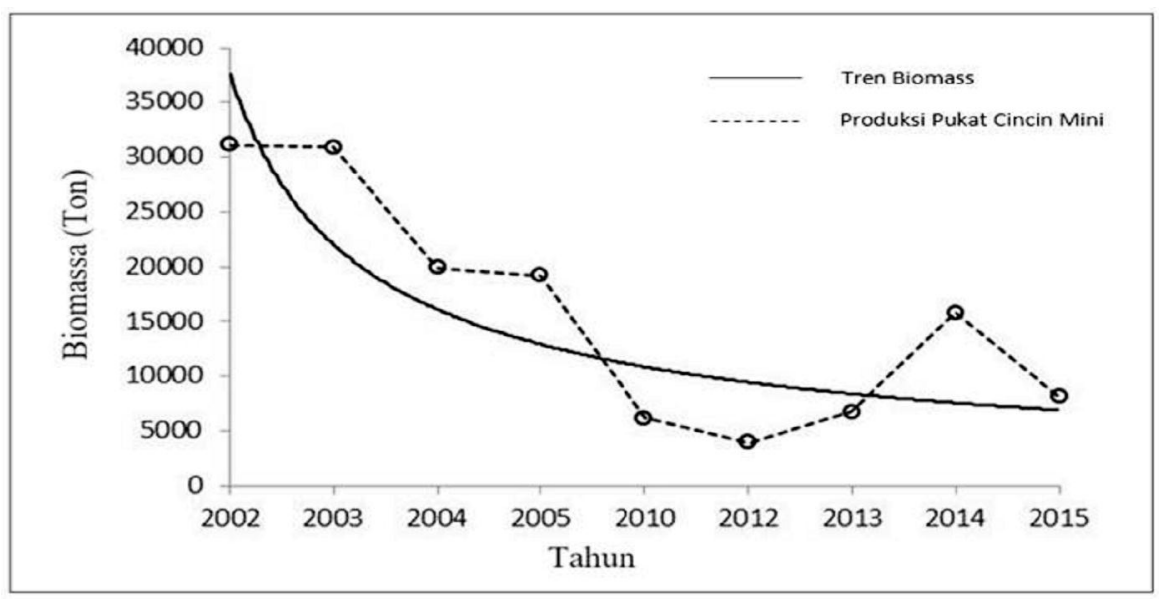

Gambar 8. Perubahan biomassa A. sirm berdasarkan produksi pukat cincin mini yang berpangkalan di PPN Pekalongan.

Figure 8. The fluctuation of A. sirm biomass based on purse seiner catches in PPN Pekalongan.

\section{PEMBAHASAN}

Penelitian yang dilakukan oleh (Atmaja \& Nugroho, 2004), menyimpulkan bahwa ikan siro (Ambligaster sirm) termasuk ikan cepat tumbuh dan berumur pendek. Ikan tersebut mengalami matang seksual pertama kali ketika umur kurang dari setahun dan tingkat mortalitasnya tinggi serta biasanya mati sebelum tahun kedua setelah musim pemijahan. Nilai b dari perhitungan hubungan panjang berat adalah 2.2598 hal ini berarti pola pertumbuhan ikan siro ini bersifat alometrik negatif di mana pertumbuhan panjang lebih cepat dari pertumbuhan beratnya, kemudian dari hasil penelitian diketahui bahwa ukuran ikan siro yang tertangkap oleh pukat cincin mini di dominasi kelompok ukuran panjang 14,8 cmFL dan belum matang gonad. Pada penelitian ini menunjukkan bahwa panjang ikan siro pertama kali tertangkap lebih kecil dari ukuran panjang ikan pertama kali matang gonad (nilai Lc lebih kecil dari nilai Lm) sama dengan hasil penelitian yang dilakukan oleh Nidya (2017), kondisi seperti ini menggambarkan bahwa ikan siro yang tertangkap menggunakan purse seine mini adalah ikan-ikan muda dan belum sempat memijah. Indikasi tersebut dapat saja terjadi ketika nelayan menggunakan alat tangkap dengan mata jaring yang kecil dan menangkap pada wilayah berkumpulnya ikan siro muda yang belum matang gonad, jika hal seperti ini terus berlanjut dikhawatirkan akan menghambat proses rekruitmen ikan siro.

Nilai indeks kematangan gonad yang kecil yaitu $4,2 \%$ menunjukkan bahwa rata - rata ikan siro yang tertangkap masih berukuran kecil dan belum matang gonad, karena semakin kecil dan ringan gonad ikan betina akan mengindikasikan ikan tersebut berukuran kecil yang biasanya pada kondisi belum matang gonad (immature). Penelitian ikan siro di Laut Jawa yang dilakukan oleh Atmaja \& Nugroho (1997) menggambarkan ikan yang tertangkap didominasi oleh ikan yang belum matang secara seksual sedangkan individu ikan yang matang seksual dan siap memijah dalam sampel hasil tangkapan berjumlah sedikit, hal yang sama juga ditunjukkan pada hasil penelitian yang dilakukan oleh Atmaja (2006) bahwa ikan siro yang tertangkap di Laut Jawa memiliki nilai indeks kematangan gonad antara 5\% - 10\% dan terindikasi bahwa kelimpahan ikan siro di Laut Jawa mengalami growth overfishing yakni perikanan yang mengeksploitasi ikan-ikan berukuran kecil yang belum sempat memijah, indeks kerentanan ikan siro lebih dari 1,8 yaitu sebesar 2,14 (Triharyuni et al., 2015). Sebagian sampel ikan siro dalam penelitian ini diambil pada periode peralihan dari musim timur ke musim barat yang di duga ikan siro belum memijah. Hasil penelitian Asriyana (2013) indeks kematangan gonad 
ikan siro yang tertangkap di Teluk Kendari pada bulan Desember adalah $4,11 \%-5,14 \%$ sama dengan ikan siro yang tertangkap di Laut Jawa, jika hal seperti ini terus berlangsung akan membahayakan keberlanjutan ikan siro.

Nelayan pukat cincin mini di PPN Pekalongan masih banyak yang menggunakan jaring dengan besar ukuran mata jaring antara 1-2 inci, untuk kelestarian ikan siro alat tangkap yang digunakan harus selektif dan jumlah armada kapalnya dibatasi, di mana selektifitas penggunaan alat tangkap dapat dilakukan dengan cara penggunaan jaring dengan ukuran mata jaring yang lebih besar dari yang biasa mereka gunakan. Kajian aspek biologi ikan siro pada penelitian ini dapat digunakan sebagai indikator kelimpahan dan menggambarkan adanya kecenderungan overfishing dengan banyak tertangkapnya ikan - ikan muda yang berukuran relatif kecil sesuai dengan penelitian Atmaja \& Nugroho (1995) yang menyatakan bahwa ikan siro hasil tangkapan pukat cincin didominasi oleh ikan muda dan reproduksinya tidak aktif. Penggunaan pukat cincin mini dengan mata jaring yang tidak sesuai peraturan (badan jaring $=22 \mathrm{~mm}$, jaring sayap $=26$ $\mathrm{mm}$ dan jaring kantong $=18 \mathrm{~mm}$ ) harus segera diganti dan disesuaikan ukurannya dengan mengacu pada Peraturan Menteri Kelautan dan Perikanan No. 2 tahun 2011 tentang alur penangkapan ikan dan penempatan alat penangkapan ikan dan alat bantu penangkapan ikan di wilayah pengelolaan perikanan negara republik indonesia tepatnya pada pasal 22 ayat 1 poin $\mathrm{b}$.

Alat tangkap pukat cincin mini dengan ukuran mata jaring yang tidak sesuai aturan yang telah ditetapkan yaitu lebih dari 1 inci atau 25,4 mm menunjukkan bahwa yang perlu diperhatikan dari pengelolaan perikanan siro di Laut Jawa adalah selektifitas alat tangkap jaring pukat cincin mini yang digunakan, oleh karena itulah perlu adanya tindakan tegas pada pelaksanaan Peraturan Menteri Kelautan dan Perikanan Nomor 02 tahun 2011 untuk menjamin kelestarian perikanan ikan siro. Pemakaian aturan terkait selektifitas alat tangkap tersebut telah dilakukan juga pada beberapa negara diantaranya perairan barat Negombo, Srilanka yang menetapkan besaran mata jaring untuk menangkap ikan siro yang menjamin kelestariannya adalah diatas $27 \mathrm{~mm}$ (Karunashinghe \& Wijeyaratne, 1991). Pada kurun waktu 10 tahun terakhir tidak mengalami perbaikan populasi ikan siro di beberapa perairan Indonesia (Nidya et al., 2017).

\section{KESIMPULAN}

Pemanfaatan sumberdaya ikan siro di Laut Jawa terindikasi tidak lestari, karena ukuran pertama kali tertangkap (Lc) belum pada ukuran matang gonad (Lm) meskipun rasio jenis kelamin ikan siro jantan dan betina secara menyeluruh adalah seimbang ini dapat menggambarkan bahwa sebagian besar ikan siro yang tertangkap belum memijah. Hal seperti ini dapat mengakibatkan growth overfishing, dimana produksi dibawah nilai maksimum tangkapan per rekruitmen (maximum yield per recruit). Produksi siro menunjukkan penurunan gardual yang dalam jangka panjang diduga tidak lagi menguntungkan bagi industri penangkapan. Perangkat pengelolaan sangat diperlukan untuk menjadi keberlangsungan usaha dan fungsi ekologi ikan siro, seperti penggunaan ukuran mata jaring yang lebih besar (misal $>2,5$ inci), pengurangan armada dan pengaturan lokasi penangkapan (zonasi). Penegakkan aturan mutlak diperlukan untuk menghasilkan manfaat yang diharapkan.

\section{PERSANTUNAN}

Terima kasih disampaikan kepada World Wide Fund for Nature (WWF) yang telah membiayai riset pendataan hasil tangkapan ikan menggunakan teknologi aplikasi Akvo Flow dan PPN Pekalongan dalam memberikan bantuan teknis kegiatan pada tahun 2014.

\section{DAFTAR PUSTAKA}

Asriyana \& Sara, L. (2013). Beberapa aspek biologi reproduksi ikan siro (Sardinella longiceps Val.) di Perairan Teluk Kendari, Sulawesi Tenggara. Jurnal Ikhtiologi Indonesia. 13(1):1-11

Atmaja, S. B. (2006). Sumber Daya Ikan Pelagis Kecil Dan Dinamika Perikanan Pukat cincin mini Di Laut Jawa Dan Sekitarnya. Jakarta.

Atmaja, S. B., \& Nugroho, D. (1995). Aspek Reproduksi layang deles (Decapterus macrosoma) dan siro (Amblygaster sirm) sebagai pertimbangan dalam pengelolaannya di Laut Jawa. Jurnal Penelitian Perikanan Indonesia, 1(3):1-10

Atmaja, S. B., \& Nugroho, D. (1997). Biologi reproduksi ikan Siro (Amblygaster sirm Clupeidae), daerah dan musim pemijahan di Laut Jawa. In Seminar Biologi ke-14, Depok: 1995) (pp. 63-67). Depok: Perhimpunan Biologi Indonesia.

Atmaja, S. B., \& Nugroho, D. (2004). Karakteristik Parameter Populasi Ikan Siro (Amblygaster sirm, Clupeidae ) Dan Model Terapan Beverton Dan Holt Di Laut Natuna Dan Sekitarnya. Jurnal Penelitian Perikanan Indonesia, 10(4).

Effendie, M. I. (2002). Biologi Perikanan. Yogyakarta: Yayasan Pustaka Nusatama.

Hoydal, K., Rorvik, C. J., \& Sparre, P. (1982). Estimation of effective mesh size and their utilization in assessment. Dana, 2, 95-96.

Jayasuriya, P. M. A. (1989). Some Aspects of The 
Biology And Population Dynamics Of Amblygaster sirm (Walbaum) From The West Coast Of Sri Lanka. Journal of the National Science Council of Sri Lanka, 17 (1)/:(1), 51 - 66.

Kasim, K., Triharyuni, S., \& Wujdi, A. (2014). Hubungan ikan pelagis dengan Konsentrasi Klorofil-A di Laut Jawa. Bawal. 6(1):21-29

Karunashinghe, W. P. N., \& Wijeyaratne, M. J. S. (1991). Selectivity estimates for Amblygaster sirm Clupeidae in the small meshed gill net fishery on the west coast of Sri Lanka. Fisheries Research, 10(3-4).

Mildenberger, T. K., Taylor, M. H., \& Wolff, M. (2017). TropFishR: an R Methods, package for fisheries analysis with length-frequency data. Ecology and Evolution, 8(11), 1520-1527. https://doi.org/ 10.1111/2041-210X.12791

Nidya, K., Mennofatria, B., \& Ridwan, A. (2017). Pertumbuhan, faktor kondisi, dan beberapa aspek reproduksi ikan lemuru (Amblygaster sirm, Walbaum 1792) di Perairan Selat Sunda. BAWAL, 9(1), 43-56.
Prasetyo, A. P., \& Natsir, M. (2010). Pengaruh Variabilitas Iklim Ekstrim terhadap perikanan lemuru di Selat Bali. In Seminar Hasil Penelitian Terbaik Tahun 2010 (pp. 21-38). Jakarta: Badan Penelitian dan Pengembangan Kelautan dan Perikanan.

Taylor, M. H., \& Mildenberger, T. K. (2017). Extending electronic length frequency analysis in R. Fisheries Management and Ecology, 24(4), 230-238. https:/ /doi.org/10.1111/fme.12232

Triharyuni, S., Satria, F., \& Wudianto. (2015). Kajian Kerentanan Beberapa Jenis Ikan Pelagis Kecil di Perairan Laut Jawa. Jurnal Litkayasa Perikanan Indonesia. 21(3):139-146

Wijopriono, \& Genisa, A. S. (2003). Kajian Terhadap Laju Tangkapan Pukat cincin mini Mini Di Perairan Pantai Utara Jawa Tengah. Torani, 13(1), 44-50.

Wujdi, A., Suwarso, \& Wudianto (2013). Biologi Reproduksi Danmusim Pemijahan Ikan Lemuru (Sardinella Lemuru Bleeker 1853) di Perairan Selat Bali. BAWAL, 5(1), 49-57. 